\title{
Export Diversification in the Gulf: The Kuwait Experience
}

\section{Athanasia Stylianou Kalaitzi ${ }^{1}$ (D) Trevor William Chamberlain ${ }^{2}$}

This study examines causality among manufactured exports, imports and economic growth in Kuwait. Much of the development literature has emphasized the important role of exports in economic growth. Export growth improves productivity through increasing specialization in the export-oriented sector and optimal resource reallocation (Giles and Williams, Journal of International Trade and Economic Development, 2000). In addition, increased foreign exchange earnings, due to export expansion, finance imports essential for export-oriented production and economic growth. In turn, economic growth can lead to further export expansion by improving physical capital and the level of technology through imports (Shahbaz, Economic Modelling, 2012; Çevik et al., Economies, 2019).

The degree to which exports accelerate economic growth and, in turn, facilitate further export expansion is dependent on the export and import categories in which the expansion takes place. Evidence from a number of countries suggests that expansion of primary exports (e.g., oil, gas and minerals) can slow down economic growth, while manufactured exports (e.g., machinery and transport equipment) can accelerate economic growth through knowledge spillover effects on both the export and non-export sectors of the economy (Sachs and Warner, European Economic Review, 2001; Behdubi et al., Journal of Economic Development, 2010; Kristjanpoller et al., Latin American Review, 2016). As for imports, primary and capital goods are essential for export sector production, especially for activities specialising in manufactured goods, in

Supplementary Information The online version contains supplementary material available at https://doi. org/10.1007/s11294-021-09825-4.

Athanasia Stylianou Kalaitzi

a.kalaitzi@1se.ac.uk

1 London School of Economics and Political Science, Middle East Centre, WC2A 2AZ, London, UK

2 McMaster University, DeGroote School of Business, 1280 Main Street West, Hamilton, ON L8S 4M4, Canada 
the form of raw materials and technology transfer, respectively (Keller, World Bank Economic Review, 2000; Awokuse, Applied Economics, 2008).

To the authors' knowledge, no study in the English language literature has examined these relationships in Kuwait. Accordingly, this study investigates whether manufactured exports contribute to economic growth and which categories of imports drive export diversification in order to achieve long-run economic growth. In doing so, the study contributes to the design of trade strategies that will foster long-run economic growth in Kuwait and in other small oil-producing countries, as the export demand for oil peaks and begins to decline.

In 2019, Kuwait was the fourth largest exporter of crude oil and petroleum products among the Organization for Petroleum Exporting Countries (OPEC) members (OPEC, Annual Statistical Bulletin, 2020). From 1970 to 2019, real manufactured exports, primary imports and manufactured imports increased at average annual growth rates of 8.9, 5.2 and 6.0\%, respectively (United Nations Comtrade Database, 1970-2019). In addition, manufactured exports as a share of total merchandise exports increased from $4.7 \%$ in 1970 to $7.8 \%$ in 2019 . The main manufactured export categories are chemicals and related products, and machinery and transport equipment (Online Supplemental Appendix Table 1). During the same period, gross domestic product (GDP) grew at a slower pace, at an average annual growth rate of $2.3 \%$, which is lower than the world average of 3.1\% (World Bank, World Development Indicators, 1970-2019).

To examine causality among manufactured exports, imports and economic growth, the study used data from 1970 to 2019 (World Bank, World Development Indicators, 1970-2019; International Monetary Fund, International Financial Statistics, 1970 2019; United Nations Comtrade Database, 1970-2019) together with an augmented Cobb-Douglas production function. In particular, aggregate output for Kuwait was expressed as a function of physical capital, human capital, manufactured exports, primary and manufactured imports.

The study examined the stationary properties of the data using the augmented Dickey-Fuller and Kwiatkowski-Phillips-Schmidt-Shin unit root tests, and the modified Dickey-Fuller test with a breakpoint. To investigate the existence of cointegration among the variables in the model, the Johansen cointegration test and dynamic ordinary least squares (DOLS) methods were applied. Short-run causality was examined using Granger causality in a vector error correction model (VECM) framework, the parameters of which were assessed by applying the cumulative sum (CUSUM) of squares test and the recursive residuals test. To investigate long-run causality among the variables, the Toda and Yamamoto test was performed.

The Johansen cointegration test showed that the variables were cointegrated, which was confirmed by the DOLS results. The Granger causality test indicated that the hypothesis of no short-run causality from manufactured exports to economic growth could not be rejected $(p=0.41)$. However, the variables in the model jointly caused economic growth $(p=0.02)$. As for the other causal relationships in the model, unidirectional short-run causality ran from economic growth to primary imports $(p=0.03)$ and to manufactured imports $(p=0.02)$. Manufactured exports caused primary imports $(p=0.05)$. The model variables jointly caused primary imports $(p=0.00)$ and manufactured imports $(p=0.02)$.

The Toda and Yamamoto test indicated that the null hypothesis of no long-run causality from manufactured exports to economic growth could not be rejected $(p=$ 
0.20). In contrast, the null hypotheses of no long-run causality from primary and manufactured imports to manufactured exports were rejected $(p=0.06$ and $p=0.01$, respectively). Concurrently, the variables in the model jointly caused manufactured exports, and primary and manufactured imports $(p=0.03, p=0.02$ and $p=0.03$, respectively) in the long run.

The study's results show that manufactured exports and disaggregated imports, together with capital and labour, contribute to short-run economic growth, which, in turn, causes import expansion. The results also indicate that expansion of both primary and manufactured imports drives export diversification in the long run, while manufactured exports do not cause economic growth.

The policy implications of this study for Kuwait, and possibly for other small oilproducing countries, are as follows. First, export diversification as a policy for economic growth would be partially effective and only in the short run. Achieving economic growth, even in the short run, requires parallel implementation of import expansion policies and investment in physical and human capital. Second, as manufactured exports expansion alone does not cause long-run economic growth, identification of the categories of manufactured exports that could foster economic growth in the long run is vital and a subject for future research.

Funding This study is funded by the LSE Kuwait Program supported by KFAS.

Open Access This article is licensed under a Creative Commons Attribution 4.0 International License, which permits use, sharing, adaptation, distribution and reproduction in any medium or format, as long as you give appropriate credit to the original author(s) and the source, provide a link to the Creative Commons licence, and indicate if changes were made. The images or other third party material in this article are included in the article's Creative Commons licence, unless indicated otherwise in a credit line to the material. If material is not included in the article's Creative Commons licence and your intended use is not permitted by statutory regulation or exceeds the permitted use, you will need to obtain permission directly from the copyright holder. To view a copy of this licence, visit http://creativecommons.org/licenses/by/4.0/.

Publisher's Note Springer Nature remains neutral with regard to jurisdictional claims in published maps and institutional affiliations. 